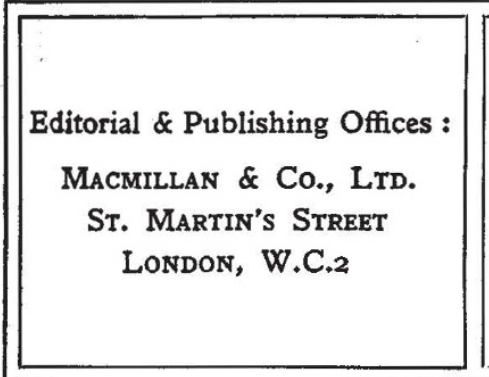

Vol. I45

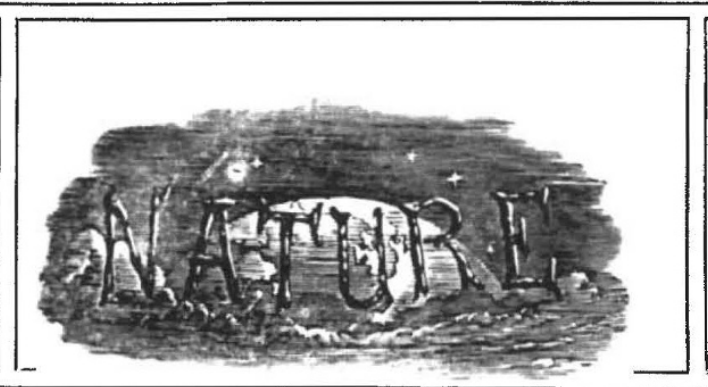

SATURDAY, APRIL 6, r940
Telegraphic Address : Phusis, Lesquare, London

Telephone Number : WhitehaLl $883 \mathrm{I}$

\title{
INTERNATIONAL UNITY IN WAR AND PEACE
}

$\mathrm{T}$ HE solemn declaration of the Supreme War Council issued in London last week states firmly and explicitly what most people have taken for granted about the unity of the Allies in war and in the making of peace. It should now be clear to the whole world that their unity is firmly established, and that it is not merely a contribution towards winning the war but will also constitute the sure and stable foundation of an enduring peace. The two Governments, desiring to extend the scope of agreements concluded last December to all spheres affecting the interests and security of the two nations, mutually undertake that they will neither negotiate nor conclude an armistice or treaty of peace except by mutual agreement, and that they will not discuss peace terms before reaching complete agreement on the conditions necessary to ensure to each of them an effective and lasting guarantee of their security.

The final declaration is even more significant. The two Governments undertake to maintain, after the signing of peace, a community of action in all spheres for so long as may be necessary to safeguard their security, and to effect the reconstruction, with the assistance of other nations, of an international order which will ensure the liberty of peoples, respect for law and the maintenance of peace in Europe. The terms of this declaration are strikingly in harmony with the recent declaration of President Roosevelt, and on that ground alone are reassuring to neutral as well as Allied, opinion and likely to promote Anglo-American understanding and good relations. More important still, confirming Sir John Simon's statement in a recent broadcast that the close Anglo-French co-operation established in every field will continue when the War has ended, it encourages the hopes which have been placed in Anglo-French co-operation as a stepping-stone to a new world order.

The declaration is open to no other interpretation than that the two Governments have accepted the responsibility for a further task when their joint forces have won for them security and the guarantee that it will endure-the organization of a new international order, capable of preserving law, liberty and peace for all nations. Already the co-operation between the two nations in the prosecution of the War itself has led them to give up their absolute sovereignty. That part of their sovereignty which they have surrendered into the common fund of authority is now to remain there at least until the new international order has been established.

This declaration, therefore, amply justifies the hopes of those who saw in the Supreme Council and the Allied High Command the germ from which might develop an international organ of government with an international police force at its command. In the light of it, again, arrangements recently concluded between the British and French Colonial Offices for pooling information and advice on problems of government in Africa may well form the basis for an extension or evolution of the mandates system, which may provide the world with an adequate and just settlement of the problems of colonies and access to raw materials. Similarly, the experience gained in the working of the economic and financial agreements will be of incalculable value.

This declaration justifies the strongest hopes of those who are concerned with the establishment of a new and enduring world order which will safeguard the liberty of peoples and respect for law, on which human progress in whatever field has 
been based, and indicates that, when the time comes to discuss larger systems of co-operation, Anglo-French collaboration will provide us with an invaluable store of wisdom on the community of ideas necessary for co-operation to be possible, and on the ends to which co-operation is desirable and possible. Already it shows us that some of the gravest weaknesses of the Treaty of Versailles and of the Covenant of the League of Nations will be avoided. The framework or constitution of the new world order will be attempted by a separate and subsequent act to the framing of the terms of peace. The declaration of March 28 may well come to assume historic significance in the evolution of world order, both as marking a stage towards the renunciation of absolute national sovereignty and in the linking of the distinctive political genius of two entire peoples in building up a system of co-operation to serve their own immediate purposes and also those of all other States subseribing to like ideals of law and justice, of freedom and humanity.

\section{EDUCATION IN THE ARMED FORCES}

$\mathrm{I}^{\mathrm{N}}$ $\mathrm{N}$ his review in the House of Commons on March 13, the Minister of War directed attention to developments in the provision of educational facilities for men in the Armed Forces. Mr. Stanley outlined the general scheme which is in operation under the rgis of the Central Advisory Council for Adult Education in H.M. Forces (Home Services), which was brought into being a few months ago. The Council is representative of organizations for adult education, and works in conjunction with regional committees set up by the vice-chancellors of universities or principals of university colleges in their own areas. The Board of Education acts as the medium through which the Central Advisory Council makes contact with the Admiralty, War Office, and Air Ministry, while the divisional inspectors of the Board take a similar part with the regional committees. The Central Advisory Council had appealed to the War Office for a sum of $£ 10,000$ "to be going on with", and help on a similar scale is being requested from the Admiralty and Air Ministry. The outcome of these applications is not clear and was not dwelt upon by Mr. Stanley in his statement, although the omission suggests that the applications have been at least temporarily shelved. It is essential that the existing situation should be clarified if misconceptions are to be avoided.

At its initial meeting, adequate testimony was reported by the Central Advisory Council to show that men and women in the Services are in pressing need of educational facilities of all kinds, including lectures and discussions, books and correspondence, and other services that have been fostered by adult education associations. The need of men and women in the Services for mental stimulation as well as for welfare and recreational facilities has frequently been neglected, a danger of which full cognizance must be taken to-day. This was not generally realized until the closing stages of the War of 1914-18, and not until 1920 was the Army Educational Corps founded as a permanent organization.

The objects of educational services were stated in an Army Order of September 24, 1918, to be : (a) to raise morale by indirectly providing mental stimulus and change, and directly by means of lectures on German methods, guns, etc. ; $(b)$ to broaden and quicken intelligence both by stimulating a desire for study and by giving men a wider realization of their duties as citizens of the British Empire; (c) to help men in their work after the War by practical instruction, so far as may be possible, in their professions or trades. When later the various educational schemes were introduced, they were eminently successful; their earlier introduction might have prevented much of the confusion that followed demobilization. Since that time, adult education has made such great strides that many men and women of the Forces to-day have been accustomed to lectures and discussions. The adoption of adequate educational measures is a matter of urgency, and one which should, if carefully planned, lead to the extension of democratic principles in a way which previously has been impossible.

The types of lectures that are likely to be most popular for men and women in the Forces have already been carefully investigated. The early experiments of the Central Advisory Council showed that the needs of the Services fall into three main groups: (1) a great demand for single lectures by authorities on such subjects as foreign affairs, history, exploration, literature 